\title{
Hepatitis B virus genotype E detected in Brazil in an African patient who is a frequent traveler
}

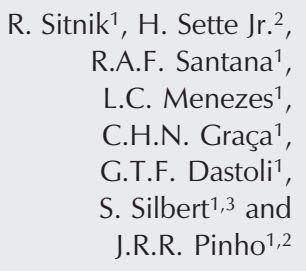

R. Sitnik ${ }^{1}$, H. Sette Jr. ${ }^{2}$,

R.A.F. Santana ${ }^{1}$,

L.C. Menezes ${ }^{1}$,

C.H.N. Graça ${ }^{1}$,

G.T.F. Dastoli ${ }^{1}$,

S. Silbert ${ }^{1,3}$ and

J.R.R. Pinho ${ }^{1,2}$

\author{
1Departamento de Patologia Clínica, Hospital Israelita Albert Einstein, \\ São Paulo, SP, Brasil \\ ${ }^{2}$ Departamento de Gastroenterologia, Faculdade de Medicina, \\ Universidade de São Paulo, São Paulo, SP, Brasil \\ ${ }^{3}$ Departamento de Infectologia, Faculdade de Medicina, \\ Universidade Federal de São Paulo, São Paulo, SP, Brasil
}

\author{
Correspondence \\ R. Sitnik \\ Departamento de Patologia Clínica \\ Hospital Israelita Albert Einstein \\ Av. Albert Einstein, 627 \\ 05651-901 São Paulo, SP \\ Brazil \\ Fone: $+55-11-3747-2122$ \\ E-mail: rositnik@hotmail.com
}

Publication supported by FAPESP.

Received February 21, 2007

Accepted July 10, 2007

\section{Abstract}

Genotype E of hepatitis B virus (HBV) has not been described in Brazil and is found mainly in Africa. Genotype A is the most prevalent in Brazil, and genotypes B, C, D, and F have already been reported. We report here an HBV genotype E-infected patient and some characterization of surface $(\mathrm{S})$ protein, DNA polymerase $(\mathrm{P})$ and precore/ core (preC/C) coding regions based on the viral genome. The patient is a 31-year-old black man with chronic hepatitis B who was born and raised in Angola. He has been followed by a hepatologist in São Paulo, Brazil, since November 2003, and he is a frequent traveler to Latin America, Africa, and Europe. In 2003, he was diagnosed with HBV infection and started treatment with lamivudine with the later addition of adefovir dipivoxil. No known risk factor was identified. Serologically, he is HBsAg and anti-HBe positive, but HBeAg and anti-HBs negative. DNA sequence analysis of the $\mathrm{S} / \mathrm{P}$ region confirmed that this patient is infected with genotype $\mathrm{E}$, subtype ayw4. The preC/C region showed G1896A and G1899A mutations but no mutations in the basal core promoter. Nucleotide substitutions common in genotype E were also observed (C1772, T1858 and A1757). Although this is not an autochthonous case and there is no evidence of further spread, the description of this case in Brazil highlights the current risk of viral genotypes spreading with unprecedented speed due to constant travel around the world.

Hepatitis B virus (HBV) is a major cause of chronic liver disease worldwide. This virus is a small DNA virus with a partially double-stranded 3.2-kb genome (1) and has been classified into eight genotypes $(\mathrm{A}-\mathrm{H})$ based on sequence divergence over the entire genome. The genotypes show a distinct and well-defined geographic distribution (2).
Key words

- Hepatitis B

- HBV genotype E

- Precore mutation

- Brazil

- Africa

- African traveler
Genotype E of HBV has not been described in Brazil and is found mainly in Africa. Genotype A is the most prevalent in Brazil, and genotypes B, C, D, and F have already been reported.

In the present study, we describe the clinical and epidemiological data of an African patient infected with HBV genotype E which 


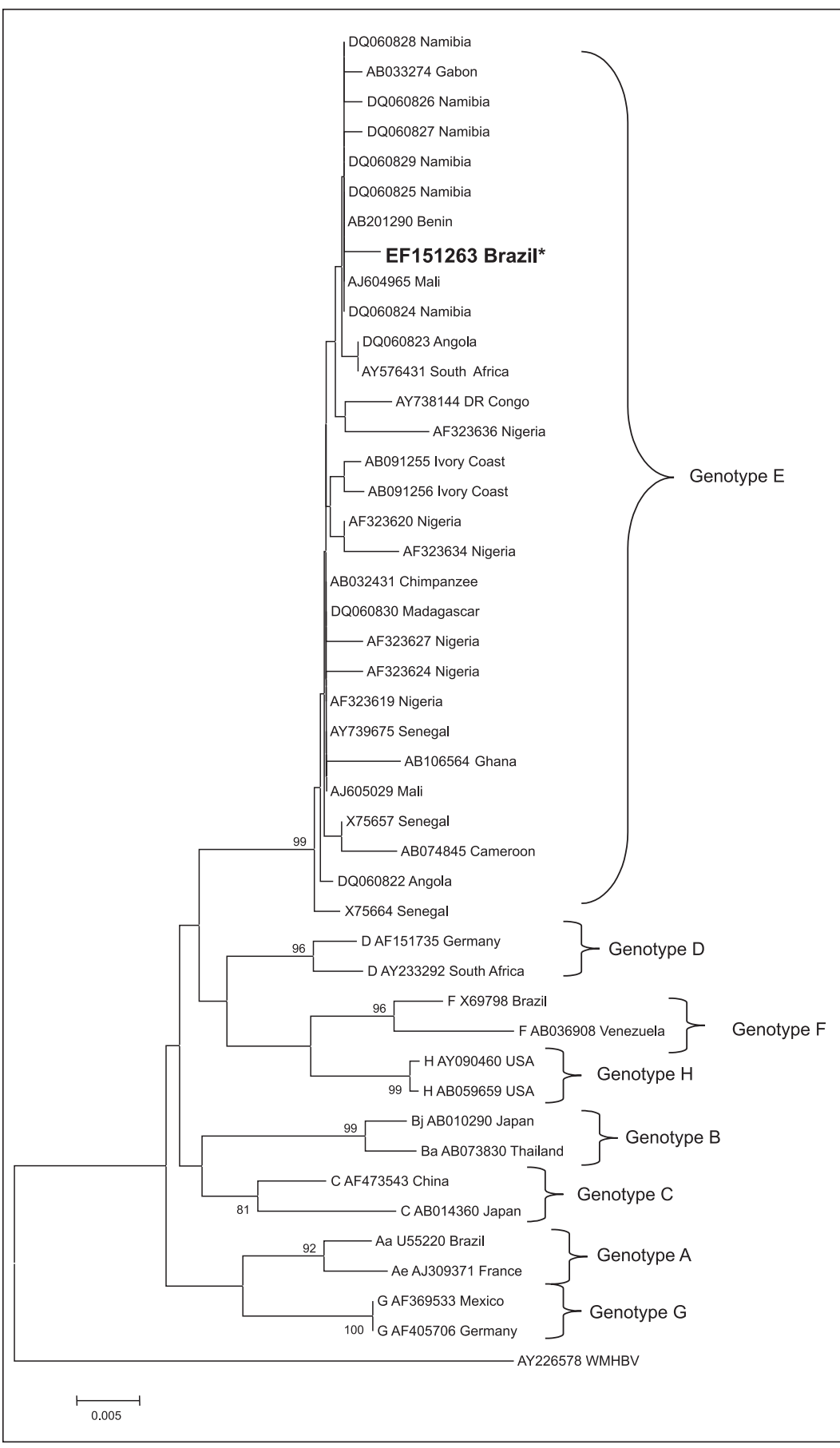

Figure 1. Phylogenetic tree. Phylogenetic analysis obtained with the MEGA3 software of a 593-bp fragment of hepatitis B virus (HBV) DNA from the index case (S gene - GenBank accession number EF151263), 29 genotype E African sequences and two sequences of each of the other HBV genotypes. The tree was constructed by the neighbor-joining method and only bootstrap values higher than 80 are shown. A wooly monkey HBV sequence was used as the outgroup. GenBank accession numbers as well as the original countries of all HBV isolates are indicated. The length of the horizontal bar indicates the number of nucleotide substitutions per site. was detected in Brazil.

The patient provided informed written consent to perform all studies described here and sequences were deposited in Genbank (accession numbers EF151263 for the S/P region and EF153194 for the precore/core region).

A 31-year-old black man with a history of chronic hepatitis B infection has been followed by a hepatologist in São Paulo, Brazil, since November 2003, when he was diagnosed with HBV infection. This patient was born and raised in Angola and, as a lawyer, he frequently travels to Latin America, Africa, and Europe. Initial treatment consisted of lamivudine but, due to low compliance, adefovir dipivoxil was added. The patient suffers from morbid obesity and systemic arterial hypertension. No known risk factor was identified. Currently, he shows normal serum levels of hepatic enzymes (alanine aminotransferase, aspartate aminotransferase, alkaline phosphatase, and $\gamma$ glutamyltransferase). Serologically, he is HBsAg and anti-HBe positive, but HBeAg and antiHBs negative. Viral load determined by real time PCR was $291 \mathrm{IU} / \mathrm{mL}$ or 3,832.66 copies/mL in August 2006, when the consulting physician also asked for genotype and antiviral resistance tests.

HBV DNA was extracted from $200-\mu \mathrm{L}$ plasma samples using the QIAamp DNA mini-kit (QIAGEN, Hilden, Germany) according to manufacturer instructions. HBV DNA was detected by nested PCR amplifying the overlapping surface antigen $(S)$ and DNA polymerase $(\mathrm{P})$ genes, as previously described $(3,4)$. For the detection of precore/ core mutants, HBV DNA was amplified using the primers described by Takahashi et al. (5). HBV genotyping was carried out by direct sequencing of the amplified product using an ABI3130 DNA sequencer analyzer and the SeqScape Software V2.5 (Applied Biosystems, Foster City, CA, USA), which compares the sequence with a database of sequences from the different genotypes, 
thereby generating a score of similarity. Sequences were submitted to BLAST in the GenBank database. A phylogenetic tree was constructed with the MEGA3 software (6) using a distance method (neighbor joining) and robustness of the tree was assessed by 1000 bootstrap replicates. The amino acid sequence obtained from the nucleotide sequence was also analyzed to assess subtype and possible drug resistance mutations in the HBV sequence.

Initial analysis of the nucleotide sequence of the S/P genomic region of HBV with the SeqScape Software V2.5 (Applied Biosystems) showed that it clustered with genotype E. Since this genotype has never been reported in Brazil, we performed a more extensive characterization of this virus. Phylogenetic analysis of the $\mathrm{S} / \mathrm{P}$ region compared with reference isolates from GenBank representing all known HBV genotypes confirmed that it was classified into genotype $\mathrm{E}$ (Figure 1), and the HBsAg subtype was identified as ayw4 based on the presence of $\operatorname{Arg}^{122}$, Lys ${ }^{160}$, $\mathrm{Leu}^{127}$, and $\mathrm{Ser}^{140}$. Val to Leu mutation at position 209, present in all genotype E HBV sequences, was also found in this patient. No other amino acid mutations were found within the $\mathrm{S}$ protein and no drug resistance-related mutations were found in the HBV DNA polymerase protein. When submitted to BLAST in the GenBank, the sequence from the $\mathrm{S} / \mathrm{P}$ region showed $99.07 \%$ similarity to several HBV genotype E sequences.

Mutation V209L is also found in genotype Aa, a discrete subtype within genotype A (7). Subgroup Aa has some amino acids differing from group Ae and was primarily found in sub-Saharian Africa. It was suggested that subgroup Aa may have evolved in indigenous populations of African countries. Later, this genotype was also found in South America $(8,9)$, suggesting that this high proportion of subgroup Aa may be due to the intense slave trade from Africa to South America during the colonial period. In another study in a city with a large percent of African descendants (Salvador, BA, Brazil), genotype A was also the most prevalent in the local population, followed by genotypes $\mathrm{D}$ and $\mathrm{F}$, but no case of genotype $\mathrm{E}$ was identified (10). The Afro-Brazilian population has a higher prevalence of HBV markers compared to other ethnic groups (11) which might be related to a higher HBV infection rate among the first black inhabitants that were brought to Brazil and/or to the low socioeconomic level of that population. The lack of other genotype E cases in Brazil and South America is very intriguing, since this genotype has a high prevalence in Africa and may also have come with the African slaves, besides subgroup Aa.

The low sequence diversity of genotype $\mathrm{E}$ in isolates from African patients over a large geographical area suggests a short evolutionary history in humans $(12,13)$. Indeed, genotype $\mathrm{E}$ has never been found within the Americas (14) or in the Afro-Brazilian population $(8,10,11,15)$, a fact suggesting the emergence of genotype $\mathrm{E}$ as a human pathogen from the mid to the late 19th century.

Analysis of the precore/core region showed G1896A and G1899A precore mutations but no mutations in the basal core promoter (BCP). In another study with genotype E-infected patients, precore mutation was detected in $75 \%$ of the patients without $\mathrm{HBeAg}$, in contrast to only $25 \%$ of the patients with $\mathrm{HBeAg}$. All the strains described so far have T1858 (16), as also does the index case described here. This substitution allows the G1896A mutation and prevents the production of $\mathrm{HBeAg}$. BCP mutation was detected in a few patients previously described and there was no relation to the presence of $\mathrm{HBeAg}(16,17)$. Other substitutions common to all genotype $\mathrm{E}$ sequences were also found (A1757 and C1772) in this patient. Mutation G1757A abolishes COUP TFI and HNF-1 nuclear factors binding to $\mathrm{BCP}$ in experiments in vitro (18) and may influence the clinical characteristics of genotype E, probably being related to the mild 
evolution observed in this case.

We described here the major features of the first HBV genotype E case found in São Paulo State, Brazil. This genotype has never been reported in Brazil. It was recently found in 2 Argentinian sisters whose mother is from the Dominican Republic (19). In Brazil, genotypes A, B, C, D, and F have already been described and their distribution varies among Brazilian regions $(4,10,20)$, suggesting an influence of the immigration pattern for each region. Further molecular epide- miologic studies of HBV genotypes in the Afro-Brazilian population would be very important to determine if other cases can be found and to assess possible correlations of genotype $\mathrm{E}$ with the clinical course of infection and response to therapy. Furthermore, although this is not an autochthonous case and there is no evidence of further spread, the description of this case in Brazil highlights the current risk of viral genotypes spreading with unprecedented speed due to constant traveling around the world.

\section{References}

1. Lee WM. Hepatitis B virus infection. N Engl J Med 1997; 337: 17331745.

2. Liu CJ, Kao JH, Chen DS. Therapeutic implications of hepatitis B virus genotypes. Liver Int 2005; 25: 1097-1107.

3. da Silva LC, Pinho JR, Sitnik R, Da Fonseca LE, Carrilho FJ. Efficacy and tolerability of long-term therapy using high lamivudine doses for the treatment of chronic hepatitis B. J Gastroenterol 2001; 36: 476-485.

4. Sitnik R, Pinho JR, Bertolini DA, Bernardini AP, da Silva LC, Carrilho FJ. Hepatitis B virus genotypes and precore and core mutants in Brazilian patients. J Clin Microbiol 2004; 42: 2455-2460.

5. Takahashi K, Aoyama K, Ohno N, Iwata K, Akahane Y, Baba K, et al. The precore/core promoter mutant (T1762A1764) of hepatitis B virus: clinical significance and an easy method for detection. J Gen Virol 1995; 76 (Part 12): 3159-3164.

6. Kumar S, Tamura K, Nei M. MEGA3: Integrated software for molecular evolutionary genetics analysis and sequence alignment. Brief Bioinform 2004; 5: 150-163.

7. Bowyer SM, van Staden L, Kew MC, Sim JG. A unique segment of the hepatitis $B$ virus group A genotype identified in isolates from South Africa. J Gen Virol 1997; 78 (Part 7): 1719-1729.

8. Araujo NM, Mello FC, Yoshida CF, Niel C, Gomes SA. High proportion of subgroup A' (genotype A) among Brazilian isolates of hepatitis B virus. Arch Virol 2004; 149: 1383-1395.

9. Motta-Castro AR, Martins RM, Yoshida CF, Teles SA, Paniago AM, Lima KM, et al. Hepatitis B virus infection in isolated Afro-Brazilian communities. J Med Virol 2005; 77: 188-193.

10. Lyra AC, Pinho JR, Mello IM, de M Malta F, Gomes MM, Di Bisceglie AM, et al. Distribution of hepatitis B virus (HBV) genotypes among patients with acute viral hepatitis. J Clin Gastroenterol 2005; 39: 8182.

11. Bertolini DA, Pinho JR, Saraceni CP, Moreira RC, Granato CF, Carrilho FJ. Prevalence of serological markers of hepatitis $B$ virus in pregnant women from Paraná State, Brazil. Braz J Med Biol Res 2006; 39: 1083-1090.

12. Kramvis A, Restorp K, Norder H, Botha JF, Magnius LO, Kew MC.
Full genome analysis of hepatitis B virus genotype $E$ strains from South-Western Africa and Madagascar reveals low genetic variability. J Med Virol 2005; 77: 47-52.

13. Mulders MN, Venard V, Njayou M, Edorh AP, Bola Oyefolu AO, Kehinde MO, et al. Low genetic diversity despite hyperendemicity of hepatitis B virus genotype $\mathrm{E}$ throughout West Africa. $J$ Infect Dis 2004; 190: 400-408.

14. Quintero A, Martinez D, Alarcon De Noya B, Costagliola A, Urbina L, Gonzalez N, et al. Molecular epidemiology of hepatitis B virus in Afro-Venezuelan populations. Arch Virol 2002; 147: 1829-1836.

15. Ribeiro NR, Campos GS, Angelo AL, Braga EL, Santana N, Gomes $\mathrm{MM}$, et al. Distribution of hepatitis $B$ virus genotypes among patients with chronic infection. Liver Int 2006; 26: 636-642.

16. Suzuki S, Sugauchi F, Orito E, Kato H, Usuda S, Siransy L, et al. Distribution of hepatitis B virus (HBV) genotypes among HBV carriers in the Cote d'Ivoire: complete genome sequence and phylogenetic relatedness of HBV genotype E. J Med Virol 2003; 69: 459465.

17. Fujiwara K, Tanaka $\mathrm{Y}$, Orito $\mathrm{E}$, Ohno $\mathrm{T}$, Kato $\mathrm{T}$, Sugihara $\mathrm{K}$, et al. Distribution of HBV genotypes among HBV carriers in Benin: phylogenetic analysis and virological characteristics of HBV genotype $E$. World J Gastroenterol 2005; 11: 6410-6415.

18. Li J, Buckwold VE, Hon MW, Ou JH. Mechanism of suppression of hepatitis $B$ virus precore RNA transcription by a frequent double mutation. J Virol 1999; 73: 1239-1244.

19. Mathet VL, Cuestas ML, Ruiz V, Minassian ML, Rivero C, Trinks J, et al. Detection of hepatitis B virus (HBV) genotype E carried - even in the presence of high titers of anti-HBs antibodies - by an Argentinean patient of African descent who had received vaccination against HBV. J Clin Microbiol 2006; 44: 3435-3439.

20. Sitnik R. Padronização de reações de seqüenciamento para caracterização do vírus da hepatite B: genótipos, subtipos, mutantes na região pré-core, promotor basal do core, epítopo "a" e resistência aos antivirais. [PhD thesis]. São Paulo: Faculdade de Medicina, USP; 2002. 